\title{
Çocuk Cinsel İstismarına Yönelik Müdahale Basamakları ve İşlevlerinin Kuramsal Olarak İncelenmesi
}

\author{
Derleme Makale / Reviewe Article
}

(iD) Faruk Caner YAM, Gaziosmanpaşa Üniversitesi

Öz

$\mathrm{Bu}$ araştırmada çocuk cinsel istismar olgusunun belirtileri, cinsel istismarın çocuk üzerindeki etkileri ve çocuk cinsel istismarına yönelik müdahale basamaklarının açıklanması amaçlanmıştır. Bu amaç doğrultusunda alan yazında yapılmış olan araştırma sonuçları ile birlikte çocuk cinsel istismar olgusunun müdahale basamakları ve bu müdahale basamaklarının etkili olma düzeyleri tartışılmıştır. Yapılan inceleme sonucunda, okul temelli önleyici çalışmaların, çocukların cinsel istismar mağduru olma oranlarındaki düşüşler üzerinde etkili olduğu sonucuna ulaşılmıştır. Ayrıca istismar mağduru çocukların istismar hikâyesinin alınmasında, oyun terapisinin, resim çizme ve öykü okuma gibi tekniklerin kullanılmasının istismar mağduru çocuğun kaygısının azaltılması üzerinde olumlu etkiye sahip olduğu görülmüştür. Diğer açıdan cinsel istismar olayı sonrasında mağdur olan çocukların sağaltım sürecinde travma odaklı bilişsel davranışçı terapinin deneysel olarak kanıtlanmış en etkili yöntem olduğu sonucuna ulaşılmıştır. Yapılan değerlendirme çalışmasının sonuçları ilgili alan yazın ışığında tartışılmış ve araştırmacılar ile politika üreticilerine çeşitli öneriler sunulmuştur.
Anahtar Kelimeler

Çocuk cinsel istismarı, müdahale basamaklar1, tedavi.

Makale Hakkında

Gönderim Tarihi: 22.10.2019 Kabul Tarihi: 24.06.2020

E-Yayın Tarihi: 25.06.2020 \footnotetext{
Abstract

The aim of this study was to explain the symptoms of child sexual abuse, its effects on the child and the intervention steps towards child abuse. In line with this aim, the results of the research conducted in the literature have been discussed together with the intervention levels of child sexual abuse and their effectiveness levels. As a result of the study, it was concluded that school-based preventive studies had an effect on the decreases in the rates of sexual abuse of children. In addition, it was seen that play therapy, drawing and story studies had a positive effect on the anxiety of the child who was the victim of abuse. On the other hand, trauma-focused cognitive behavioral therapy is the most experimentally proven effective method in the treatment process of children who are victims of sexual abuse. The results of the evaluation study were discussed in the light of relevant literature and various suggestions were presented to researchers and policy makers.
}

Theoretical Investigation of Intervention Steps and Functions of Child Sexual Abuse

Keywords Child sexual abuse, intervention steps, treatment. 


\section{Giriş}

Cinsel istismar günümüzde çocukların karşı karşıya kaldığı en önemli sorunlardan biridir (Çeçen, 2007). Çünkü istismar olgusu, çocukların yüz yüze kaldığı en eksi ve en derin toplumsal problemlerin başında gelmektedir (Teeuw, Derkx, Koster, ve van Rijn, 2012). Bu olgunun nedenleri, oluşum biçimi ve etkileyen faktörlerin bilinmesi, tanınması ve engellenmesi karışık bir süreçtir (Taner ve Gökler, 2004; Eslek, 2018). Çocuk cinsel istismarı, çocuktan en az 5 yaş büyük olmak şartı ile cinsel arzularını gidermek için çocuğun kullanılması olarak açıklanmaktadır (Kır, 2013). Toplum içinde bu vakaların yaşanma sıklığı yüksek olmasına rağmen genellikle vakaların sadece \%15'inin bildirildiği düşünülmektedir (CAPA, 2018). Cinsel istismar olgularında sadece cinsel penetrasyon dikkate alınmamakta, ayrıca sözel istismar (açık seçik konuşma), sürtünme, cinsel bölgelere dokunma veya dokundurma gibi yollarla da gerçekleştirilebilmektedir. Bu nedenle istismar mağduru çocuk değerlendirilirken biyolojik, psikolojik ve davranışsal açıdan değerlendirilmelidir (Saunders, Berliner ve Hanson, 2003). Çünkü istismara uğramış çocuklar gerçek bir değerlendirmeye tabi tutulmadıklarında, istismar durumu kaçırılabilmekte ve bu çocuklara gerekli yardımlar sağlanamamaktadır (Acehan, Bilen, Ay, Gülen, Avcı ve İçme, 2013). Dünya Sağlık Örgütü’nün verilerine göre, 1-14 yaş arasındaki kırk milyon çocuğun cinsel istismarın herhangi bir türü ile karşı karşıya kaldığı belirtilmektedir (Gilbert, Widom ve Browne, 2009). S1klığ1 ve yaygınlığ1 bu denli yüksek olan çocukluk çağı cinsel istismar olgusunun nedenlerinin iyi tanımlanmasının, çocuklardaki olası belirtilerin iyi gözlenmesinin ve istismar mağduru çocuğa yönelik gerekli tedavinin sağlanmasının toplumsal ruh sağlığının tüm paydaşlarının en önemli ve kritik görevi olduğu kaçınılmazdır.

$\mathrm{Bu}$ çalışmada, çocuk cinsel istismar olgusu, çocuk üzerindeki etkileri, müdahale basamakları ve bu müdahale basamaklarının etkililiği ile ilgili yapılmış çeşitli çalışmaların sonuçlarının kuramsal olarak alan yazın ışığında değerlendirilmesi ve son olarak müdahale basamakları ile ilgili yapılan çalışmaların çocuk cinsel istismarını önleme ve tedavi etme konusundaki etkililiğinin tartışılması amaçlanmıştır.

\section{Yöntem}

\section{Araştırmanın Modeli}

Araştırmada nitel araştırma tekniklerinden doküman inceleme yöntemi kullanılmıştır. Bu yöntemde, araştırmacı incelemek istediği olgu ve olaylarla ilgili bilgileri içeren yazılı dokümanları inceleyerek araştırması ile ilgili bilgileri toplamakta ve bunları sınıflandırmaktadır (Yıldırım ve Şimşek, 2006). Bu çalışmada da çocuk cinsel istismarı ile ilgili kuramsal bilgiler taranmış ve alan yazında çocuk cinsel istismarını (çocuk üzerindeki etkileri, belirtileri), tedavi yöntem ve süreçlerini araştıran makaleler incelenmiştir. İnceleme sonucunda elde edilen bilgiler çocuk cinsel istismarındaki risk faktörleri, çocuklarda görülen cinsel istismarın belirtileri, cinsel istismarın çocuk üzerindeki etkileri, çocukların cinsel istismarı bildirmedeki sorunları ve çocuk cinsel istismarı na yönelik müdahale basamakları ve tedavi yaklaşımları başlıkları oluşturularak sunulmuştur.

\section{Bulgular}

Doküman inceleme sonucu çocuk cinsel istismarı ile ilgili elde edilen bilgiler yöntem kısmında ifade edilen başılılar altında toplanarak sunulmuştur. 


\section{Çocuk Cinsel Ístismarında Risk Faktörleri}

Çocuk cinsel istismarı, genellikle aile işlevi bozulmuş aile yapılarında görülmektedir (Yılmaz, 2013). Çocuk cinsel istismarı vakalarında çocuk, anne ve baba arasındaki ilişkinin zayıf veya çatışmalı olduğu dikkati çekmektedir (Finkelhor, 1990). Ayrıca ailede çocuk sayısının fazla olması, sosyo-ekonomik durumun düşük olması, babanın alkol kullanımı ve psikiyatrik bozukluklar gibi durumların varlı̆̆1 risk faktörü olarak değerlendirilmektedir (Sandalcı, 2004; Yağmur ve ark., 2008; Walsh ve ark., 2002). Diğer açıdan üvey ebeveyn sahibi olmak, annenin eğitim düzeyinin düşük olması, annenin aşırı koruyucu olması, göç durumunun olması ve yaşanan yerde güvenlik zafiyetinin olması çocukların cinsel istismara uğrama riskini arttırmaktadır (Fergusson ve ark., 1997). Çünkü cinsel istismar vakalarında ebeveynlerin duygusal ve davranışsal durumlarının önemli birer belirleyici faktör olduğu değerlendirilmektedir (Cohen ve Mannarino, 1998; Hanson ve ark. 1992). Diğer bir risk faktörü ise cinsiyettir. Kız çocuklarının erkek çocuklara göre on kat daha fazla istismara uğradığı bildirilmektedir (Fergusson ve vd., 1996; Feiring ve vd., 1999). Ayrıca çocukların bedensel veya zihinsel engelinin olmasının, itaat etme eğiliminin ve ilgi görme ihtiyacının fazla olması gibi durumların çocuklarda, istismar mağduru olma olasılıklarını artırdığı değerlendirilmektedir (Aktepe ve ark., 2013; Soylu ve ark., 2012).

Çocuk cinsel istismarındaki bir diğer risk faktörü ise istismar mağduru çocuğun bu durumu bildirmede konusunda yaşamış oldukları sorunladır. Çünkü cinsel istismara uğrayan çocukların bu durumu açığa vurma ve ifade etme konusunda gecikmesinin birçok sebebi bulunmaktadır (Alaggia, 2005; Hershkowitz, Lanes ve Lamb, 2007). Bunlardan birisi, çocuğun bilişsel ve dil alanında gelişim düzeyidir. Çocuk içinde bulunduğu gelişim döneminden dolayı yaşadığı olayı gerek algılamakta, gerekse dil becerilerini kullanarak ifade etmekte zorlanabilmektedir (Paine ve Hansen, 2002). Diğer sebepler arasında, çocuğun utanması, tehdit edilmesi, istismarcının tanıdık olması ve kendisine inanılmayacağı düşüncesi gibi faktörler yer almaktadır (DeVoe ve Faller, 1999). Diğer açıdan cinsel istismar olayından istismarcı kişi aileden biri ve yakın akraba olduğu durumlarda istismar mağduru çocuk kendisinin ve ailesini başına kötü bir şey gelebileceği korkusu ile bu durumu saklayabilmektedir.

\section{Çocuklarda Görülen Cinsel Ístismar Belirtileri}

İstismar mağduru çocuklar kendilerini yetişkinler gibi ifade edemedikleri için istismara uğramış çocukların psikolojik, biyolojik ve davranışsal belirtileri dikkatli bir şekilde gözlenmelidir. Bu belirtiler genellikler travma sonrası stres tepkileridir (Yılmaz, 2013). İstismar mağduru çocuklarda cinsel içerikli davranışlarda artış, geceleri altını ıslatma, okul devamsızlığ ve akademik başarıda düşüşler, sinirlilik, hareketlenme, regresyon davranışları, depresyon, kayg1, kişiler arası ilişkilerde korku, dikkat eksikliği ve uyku bozukluğu gibi belirtiler gözlenebilmektedir (Mannarino ve Cohen, 1986, Taner ve Gökler, 2004; Şimşek, Çı̆̆ıl-Fettahoğlu ve Özatalay, 2011; Webster, 2001). Ayrıca istismar mağduru çocukların yetişkinlere olan güvenlerinde azalma, aşırı derecede utanç, sıkılma ve topluluk içine çıkmama gibi durumlar da ortaya çıabilmektedir (Bozkurt, Yorulma ve Düzkaya, 2014).

Yukarıda ifade edilenlerin yanında cinsel istismar mağduru çocuklarda gözlenen belirtiler aşağıda özetlenmiştir:

- Aşırr ağlama

- Sinirlilik veya öfke nöbetlerinde artış 
- Belirli bir kişinin veya nesnenin korkuları

- Saygısız davranışlar

- Başkalarına karşı saldırganlık

-Zayıf okul performansi

- Pantolonun 1slatilmasi veya lekelenmesi

- Cinsel davranış hakkında o yaştaki bir çocuktan beklenenden daha fazla şey bilmesi

- Cinselleştirilmiş oyun (örneğin diğer çocuklarla cinsel ilişki benzeri hareketler yapmak)

- Çocuğun davranışında beklenmedik bir değişiklik (örneğin, içine kapanma veya yüksek derecede histerik olma-teşhirci davranışlar)

- Okul aktivitelerinde düşüşlerin yaşanması

- Saldırganlık davranışlarının oluşması

- Kıyafetlerini değiştirirken ya da kıyafetleri değiştirilirken problemler yaşaması şeklinde belirtiler gözlenmektedir (Gümüş, 2017; Tackett, 2002; Pelcovitz, Kaplan ve Goldengerg, 1994).

\section{Cinsel İstismarın Çocuk Üzerindeki Etkileri}

Cinsel istismar çocuk üzerinde psikolojik, biyolojik, davranışsal ve toplumsal açıdan birçok olumsuz etki yaratmaktadır. Bunların en başında kaygı bozuklukları, uyku bozuklukları, dikkat eksikliği ve hiperaktivite bozukluğu, kabuslar, fobiler, bedensel yakınmalar, enürezis ve enkoprezis, cinsel kimliğinden iğrenme, insanlara güven duygusunda uzun süreli zedelenme gibi olumsuz etkiler gelmektedir (Ayan ve Bilican Gökkaya, 2018; Eslek, 2018). Yukarıda ifade edilen etkilerin yanında cinsel istismar mağdur üzerinde olumsuz olarak üç temel etki yaratmaktadır:

Cinsel istismara uğrayan çocukların güven duygular ciddi şekilde sarsılmaktadır (Jenny, Roesler ve Poyer, 1997). Çünkü küçük yaştaki çocukların genellikle güven hissettikleri bir yetişkin tarafindan cinsel istismara uğradıkları dikkati çekmektedir (Dube ve Herbert, 1988). Sevdikleri ve güven duydukları kişiler tarafindan cinsel istismara uğramak, çocuğun çevresine, diğer insanlara olan güven duygusunun zedelenmesine ve kendisini yakınları tarafından ihanete uğratılıış gibi hissetmesine yol açmaktadır. Cinsel istismar mağduru çocuklarda oluşan diğer bir olumsuz durum ise gücsü̈llïk ve çaresizlik hissidir. Kendisinden büyük biri tarafından zor kullanılan ve istismar edilen çocuk bunu engelleyemediği için kendisini güçsüz ve çaresiz hissedebilmektedir. Tekrarlayan istismar vakalarında ise bu durum daha şiddetli olarak kendini göstermektedir. Damgalanmak cinsel istismar mağduru çocuklarda ortaya çıkabilecek diğer bir olumsuz durumdur. Çünkü istismar mağduru çocuk suçluluk, utanç ve kirlenmişlik gibi duyguları çok yoğun bir şekilde hissetmekte ve kendisine yönelik olumsuz duygular geliştirebilmektedir.

Çocuk cinsel istismarının çocuk üzerinde oluşturmuş olduğu çaresizlik ve güçsüzlük, güvensizlik ve damgalanma gibi temel olumsuz etkilerinin yanında çok daha fazla ve uzun süreli etkileri bulunmaktadır. Bunların;

- Kayg1 bozukluklar1,

- Kabuslar, uyku sorunları, kötü rüyalar

- Dikkat eksikliği ve hiperaktivite bozukluğu,

- İdrar ve dışkı kaçırma sorunu, 
-Depresyon,

- Cinsel kimliğinden iğrenme,

- Bedensel kıyım,

- Kendini cinsel olarak kullandırma,

- Öfke tepkileri, zayıf dürtü kontrolü,

- Kişiler arası ilişki kurma ve sosyal ilişkileri sürdürebilme becerisinde zayıflık,

- İnsanlara güven duygusunda uzun süreli zedelenme gibi olumsuz etkiler oluşturmaktadır (Akduman ve ark., 2005; Göker ve ark., 2010; Shapiro ve Levendosyky, 1999; Vural ve ark. 2013)

\section{Cinsel Ístismar Müdahale Basamakları ve Tedavi Yaklaşımları \\ Birincil Düzey Müdahale (Olay Öncesi)}

Birincil düzey müdahale basamağı, okulun her kademesinde bulunan öğrencilere ve velilerine yönelik, onların gelişim düzeylerine göre düzenlenmiş, önleyici ve bilgilendirici olarak verilen eğitim çalışmalarını içermektedir. Ayrıca risk altındaki (anne-babası boşanmış ya da ayrı yaşayan, ekonomik zorlukları olan vb.) çocukların cinsel istismara yönelik bilgilenmeleri sağlanarak cinsel istismardan korunmaya yönelik çocuğun ve ailesinin bilgi ve beceri açısından güçlendirilmesi amaçlanmaktadır (Eslek, 2018; Çeçen, 2007; Kır; 2013). Bu çalışmalar;

a. İyi Dokunuş-Kötü Dokunuş Eğitimi

b. Bedenim Özel, Ben Özelim Eğitimi

c. Hayır Diyebilme Beceri Eğitimleri

d. Benim Alanım Özel Alanım

e. Cinsel İstismardan Korunma Psiko-Eğitim Programları

f. Anne-Babaya Yönelik “Çocuk Cinsel İstismarı ve Koruma Yolları” Eğitimleri şeklinde sıralanabilir.

Bu basamakta sunulan önleyici ve koruyucu hizmetlerin büyük çoğunluğu, okul rehberlik servislerinde görevli olan psikolojik danışmanlar tarafindan sunulmaktadır. Millî Eğitim Bakanlı̆ı artan cinsel istismar vakarından sonra 2009-2010 Eğitim-Öğretim Yılı'ndan bu yana ilkokula yeni başlayan çocuklara ve velilere yönelik bilgilendirici ve önleyici seminerler düzenlemektedir. Bu seminerler kapsamında öncelikli olarak çocuklara mahremiyet kavramı ve bedenindeki mahremiyet bölgeleri ile ilgili eğitimler (Bedenim Özel Ben Özelim) verilmektedir. Daha sonra ise istismara maruz kalma anında, çocuğun bu durum ile nasıl baş edebileceği ve kimlerden yardım isteyebileceği yönünde eğitimlerle devam edilmektedir. Alan yazında çocukluk çağında cinsel istismardan korunmaya yönelik önleyici çalışmalara katılan çocukların, yaşamlarında herhangi bir döneminde cinsel istismar mağduru olma sıklıklarının daha düşük olduğu belirtilmektedir. Örneğin, Gibson ve Leitenberg (2000), 825 üniversite öğrencisiyle yapmış oldukları bir araştırmada, bu öğrencilerden ilkokul kademesindeyken cinsel istismardan korunma programına katılmış olan üniversite öğrencilerinin, bu programlara katılmayan öğrencilere göre daha az cinsel istismara maruz kaldıklarını sonucu elde edilmiştir.

Yine başka bir çalışmada (Davis ve Gidyez, 2001), 3-13 yaş aralığındaki çocuklara yönelik yapılmış olan okul eğitimi kapsamında düzenlenen cinsel istismarı önleme eğitimleri ile ilgili yirmi yedi çalışma incelenmiştir. 
İnceleme sonucunda, 3-13 yaş aralığındaki çocuklara okullarda cinsel istismardan korunma ile ilgili verilen eğitimlerin çocukların cinsel istismardan korunmaya yönelik bilgi ve becerilerinin artırılmasında etkili olduğu sonucuna ulaşmışlardır. Lundgren ve Âmin (2015) yapmış oldukları çalışmada, 10-19 yaş grubuna yönelik okul temelli cinsel istismardan korunma programlarının etkili olma düzeylerini değerlendirmişler ve sonuç olarak okul i çerisinde verilen bu eğitimlerin etkili olduğu sonucunu ifade etmişlerdir. Aynı şekilde Irmak ve arkadaşlarının (2018) okul öncesi çocuklarda "Mika ile Kendimi Koruyorum" isimli cinsel istismar programının deneysel bir modelde uygulaması gerçekleştirilmiş ve sonuç olarak okul öncesi çocuklara uygulanan bu programın çocukların cinsel istismardan korunma düzeyleri üzerinde etkili olduğu sonucuna ulaşılmıştır. Tüm bu araştırma sonuçları okullarda çocuklara sunulan cinsel istismardan korunmaya yönelik önleyici çalışmaların ne denli kritik ve önemli olduğuna işaret etmektedir.

Okullarda, çocuklara yönelik düzenlenen cinsel istismardan korunma ile ilgili önleyici çalışmalar, ailelerle birlikte eş zamanlı olarak sürdürülmektedir. Çünkü, çocukların cinsel istismar mağduru olmalarında ailelerin bilgi eksikliği, davranışsal tutumları ve olumsuz yaklaşımları risk faktörü oluşturmaktadır (Fang ve vd.., 2015; Çeçen, 2007; Lereya ve vd., 2013). Bundan dolayı çocukların cinsel istismardan korunmalarında ailelere verilen eğitimlerin büyük önemi bulunmaktadır. Chen ve Chan (2015), ebeveynlere yönelik düzenlenen çocuk ihmal ve istismar programlarının etkililiklerini değerlendirdikleri çalışmalarında, eğitim alan ebeveynlerin çocuklarının ihmal ve istismar risk potansiyellerinde azalmanın meydana geldiğini rapor etmişlerdir. Yine aynı şekilde ihmal ve istismar açısından dezavantajlı ve riskli bir aile yapısında olan çocukların evlerine gerçekleştirilen ziyaretlerin olumlu sonuçlar ortaya çıardığı ifade edilmiştir (Avellar ve Supplee, 2013).

Bu basmakta öğrenciye, aileye ve öğretmene verilecek olan önleyici ve bilgilendirici eğitimlerin, çocukların cinsel istismar mağduru olma durumlarını azalttığı ilgili araştırmaların sonuçlarından anlaşılmaktadır. Bundan dolayı çocuk cinsel istismarı ile mücadeledeki en kritik basamak olan birinci düzey müdahale hizmetlerinin tüm okullarda planlı ve aktif bir şekilde sürdürülmesi ve bu konuda en öndeki sorumlulardan olan öğretmen ve okul yönetiminin bu çalışmalara aktif bir şekilde katılımı, çocukların cinsel istismar mağduru olma sıklıklarında azalmalar sağlayacaktır. Sonuç olarak, birinci düzey müdahale hizmetleri çocuk cinsel istismarıly mücadelenin en temel ve kritik basamağıdır.

\section{Íkinci Düzey Müdahale (Olayın İf̧sası)}

$\mathrm{Bu}$ aşama, cinsel istismara uğramış çocuğun olayı açığa vurduğu ve istismar olgusuna ilişkin öykünün alındığı ve değerlendirildiği müdahale basamağıdır (Van Bijleveld, Dedding ve Bunders- Aelen, 2015; Viviani, 2011). Ayrıca bu müdahale basamağında çocuğun istismar olayını ifade etmede yaşamış olduğu zorlukları giderme, güvenliğinin sağlanması, çocuğun korunması ile ilgili yasal düzenlemeleri ve danışmanlık tedbirleri planlanmaktadır. $\mathrm{Bu}$ aşamada psikolojik danışmanın dikkat etmesi gereken en temel süreç ilk görüşmedir. Görüşme sırasından çocuğun yaşamış olduğu istismar olayı daha rahat anlatabilmesi için,

- Güven ortam1,

- Samimi ilgi ve anlatım için baskıdan uzak durulması,

• Günlük sohbet, 
- Çocuğun dilinin kullanımı,

- Resimlendirme,

- Oyunla somutlaştırma gibi koşullar sağlanmalıdır (Çeçen, 2007; Kaytez ve ark., 2018).

Cinsel istismarın bildiriminden sonra yapılacak ilk görüşme ve kurulacak ilk samimi ilişki çocuğun istismar olayını anlatmasına destek olacaktır (Sternberg ve vd., 1996). Bu süreçte çocuğun istismar olayından bahsetmesi için baskı yapılmamalı ve gereksiz sorular sorulmamalıdır (Hershkowitz, 2002). Çocuğun yaşamış olduğu travmatik durumu yetişkin gibi anlatması beklenemez. Görüşme sırasında bu noktalara dikkat edilerek sabırlı olunmalıdır. Ayrıca bu görüşme sırasında çocuğun kendi oluşturmuş olduğu dilsel anlatım bozulmamalıdır. Çünkü bu süreçte çocuk kendi içerisinde tutarlı bir şeyler anlatıyor olabilir (Saywitz ve vd., 2011). İlk görüşme sırasında yapılacak en temel etkinlik çocuğun rahatlamasını sağlamak ve kuvvetli güven ilişkisi oluşturmaktır. Bu nedenle olayın ortaya çıkması basamağında çocuk açısından her türlü hassasiyet gözetilmelidir.

Türk Ceza Kanunu'nun (TCK) 279. maddesi gereği "cinsel istismar şüphesi dahi bildirilmelidir” hükmü tüm okul çalışanlarını, yasal açıdan sorumluluk altına almaktadır. Fakat okul çalışanları ve paydaşları çocuk cinsel istismar olayının ortaya çıkması ve bildirimi konusunda huzursuzluk ve isteksizlik yaşayabilmektedir. Bunun nedenleri incelediği zaman okul çalışanlarının başının belaya girmesi korkusu, ebeveynlerden tehditler alınması, okul yönetiminin çekimser kalması ve cinsel istismar belirtileri konusunda yeterli bilgilerinin bulunmaması faktörleri karşımıza çıkmaktadır (Page ve Page, 2011). Ancak okul tabanlı cinsel istismarı önleyici çalışmaların, çocukların ihmal ve istismardan korunmasında kritik rol oynaması gibi, olayın ortaya çıarılması ve bildirimi konusunda çocukların cinsel istismar ve tekrarlarından korunması açısından da okul çalışanlarının rol ve sorumlulukları büyük önem taşımaktadır. Bundan dolayı bu konuda okul çalışanlarının bilgilendirilmesi ve cinsel istismar olayını bildirim sonrasındaki yasal güvenceleri hakkından çeşitli çalışmaların yapılması, cinsel istismarın belirli nedenlerden dolayı görmezden gelinmesi durumlarını azaltacaktır.

$\mathrm{Bu}$ aşamada, çocuktan istismar ile ilgili öykü alınırken, çocukta tehdit ve cezalandırma hissi uyandıracak davranış ve kelimelerden uzak durulmalıdır. Çünkü çocuklar baskıya maruz kaldıklarında ve anlaşılmadıklarını hissettiklerinde istismar olayını inkâr edebilmektedirler (Van Bijleveld, Dedding ve Bunders-Aelen, 2015). Çocukla yapılan terapide çocuğun öyküsünü anlatmasına yardımcı olmak, güçlü duygularını yaşayabilmesi, zor ve acı olsa da yaşadıklarını anlatabilmesi için ortam sağlamak ve terapötik değişime yardımcı olmak gerekir. Bundan dolayı çocukların kendilerini daha rahat ifade edebilecekleri bazı yöntem ve teknikler kullanılmaktadır. Bu yaklaşımlar oyun terapisi, çizim yapma, boyama çalısmaları, hayvan destekli terapi, kitap ve öykü kullanımını kapsamaktadır (Geldard ve Geldard, 2013). Bu aşamada kullanılan teknik ve yaklaşımlardan, üçüncü basamak müdahale hizmetlerindeki sağaltım süreçlerinde de faydalanılmaktadır. Bu basamakta kullanılan teknikler aşağıda sunulmuştur.

\section{Oyun Terapisi}

$\mathrm{Bu}$ aşamada çocuktan cinsel istismar öyküsünün alınmasında zorlanılırsa oyun terapisine başvurulabilir (Bulut, 2016). Çocuklar yetişkinler düzeyinde kelime dağarcığına ve yaşantılara sahip olmadıkları için çocukların duygularını dilsel olarak aktarımları zor olabilmektedir. Oyun terapisi esnasında ise terapist, yapmış olduğu gözlemler neticesinde cinsel istismara uğramış çocukların bazı tipik davranışlar sergilediğini belirleyebilmektedir (Homeyer ve 
Landreth, 1998). Yine aynı araştırmacıların (Homeyer ve Landreth, 1998) cinsel istismara uğramış çocuklarla yapmış oldukları bir çalışmada, çocukların oyun esnasında sergilemiş oldukları davranışları belirlemeyi amaçlamışlardır. Bu çalışmanın sonucunda cinsel istismara uğramış çocukların oyunlarının cinsellik içeren, çatışmacı, saldırgan ve belirsiz-tutarsız tarzda olduğu sonucunu ifade etmişlerdir.

\section{Kum Terapisi}

Cinsel istismara uğrayan çocuklardan istismar öyküsünün alınmasında ve izleyen süreçlerde diğer kullanılabilecek yöntem ise kum terapisidir. Kum terapisi, çocuklar için herhangi bir anlama gelebilecek her türlü oyuncak ve nesnelerin hazır bulundurularak, çocuğun bu nesneleri özgür bir şekilde seçerek kendi öyküsünü anlatmasına yardımcı olunan bir yaklaşımdır (Grubbs, 1995). Kum havuzu tekniğinin amacı, çocuğun sözel olarak anlatmakta zorlandığı yaşantılarını çeşitli nesnelerle temsil ederek, bir hikâye oluşturmasına firsat vermektir. Grubbs (1995), cinsel istismara uğramış çocuklarla yapmış olduğu kum terapisi ile cinsel istismara uğramamış çocuklarla yapmış olduğu kum terapisi arasında çocukların öykü temsilleri açısından farklılıklar olduğunu tespit etmiştir. Çalışmanın sonucuna göre cinsel istismara uğramamış çocuklar sosyal ortamlarla ilgili sahneleri daha olumlu olarak temsil ederken, istismar mağduru çocukların bu ortamlardan çekinen ve mutsuz, bu alanları kendilerine zarar verme eğilimi olan alanlar olarak tasvir ettikleri gözlenmiştir.

\section{Resim/Çizim ve Boyama}

Sözel olarak ifade etme güçlüğü yaşayan çocuklar, çizim ve boyama gibi çalışmalarla kendisine ait bit öykü oluşturarak, duygu ve düşüncelerini daha rahat ifade edebilmektedirler. Bu teknikte, çocuk resim çizme işlemini tamamlamasının ardından terapist, çocuk tarafından çizilen resim hakkında çocukla birlikte konuşabilir, ancak bu sırada çocuğa sorgulama ve tehdit unsuru içeren sorulardan uzak durulmalıdır. Ayrıca süreç içeresinde çocuğa geri bildirim verilebilir ve amaca yönelik olmak koşulu ile çeşitli yansıtmalarda bulunulabilir.

Cinsel istismar mağduru çocukların çizmiş oldukları resimlerde cinsel organ temsilleri, yanlş̧ çizilmiş insan figürleri, çizmiş oldukları insan resimlerine cinsel organları da yer verdikleri görülmektedir (Renvoize, 1993). Diğer açından bu çocukların, insan vücudu çizimlerinde insana ait olan çeşitli kısımları eksik, yarım ve orantısı bir şekilde çizdikleri gözlenmiştir. Ayrıca çizimlerinde belirli bölgelere vurgu yaptıkları da görülebilmektedir. Aşağıda bununla ilgili örnek resimlere yer verilmiştir.

Katz, Barnetz ve Hershkowitz (2005-2007) araştırmacılar tarafindan arasında yapılan bir çalışmada cinsel istismara uğramış 4-14 yaş aralığında 125 çocuk ile ön görüşme yapılmıştır. Daha sonra çocuklardan deney ve kontrol grupları oluşturulmuştur. Çizim grubunda bulunan çocuklardan yaşamış oldukları istismar olgusunu resim çizerek anlatmaları istenmiştir. Bu çalısmanın ardından, ön görüşmedeki bilgiler ile çizilen resim dikkate alınarak çocukların yaşadıkları istismar olayını anlatmaları istenmiştir. Kontrol grubundaki çocuklarla resim çizme çalışması yapılmamış ve çocukların sadece oyun oynamalarına izin verilmiştir. Uygulama sonucunda çocuklara kendilerini nasıl hissettikleri sorulmuş ve resim yapan çocukların duygusal olarak kedilerini daha iyi hissettikleri sonucuna ulaşılmıştır. Buradan hareketle istismar mağduru çocuklarla yapılan resim çalışmalarının, çocukların kaygı durumlarının azalmasını desteklediği ve kendilerini daha rahat ifade etmelerini sağladığı sonucuna götürmektedir. 


\section{Öykü ve Kitap Tekniği}

Öykü ve kitaplar olay öncesinde çocuklara çeşitli hikâyeler ile cinsel istismardan korunma yollarının öğretilmesi yanı sıra istismar mağduru çocuğun hikayelerle, yaşantısal bağlantılar kurarak kendisini anlatmasını kolaylaştırmak amacıyla kullanılmaktadır. Öyküler yoluyla, çocuğun korkularını ve sıkıntılarını öyküde geçen herhangi bir karakterle özdeşim sağlayarak, iç dünyasını aktarmasına yardım edilebilmektedir. Öyküler, istismar mağduru çocuğun yaşamış olduğu olayı kavraması, analiz etmesi ve yaşamış olduğu problemlerle nasıl başa çıkabileceği üzerinde düşünmesi ve farklı çözüm yollarına ulaşması açısından destek olabilmektedir. Herman (1997) yapmış olduğu araştırmasında, istismar mağduru çocukla yapılan öykü anlatımı ve öyküdeki karakterleri canlandırma çalışması sonucunda, çocukların kaygı hissinin azaldığını ve yaşamış olduğu olayla ilgili durumları daha rahat yansıttıklarını gözlemlemiştir.

Kısacası istismar olayının ortaya çıarıldığı ve çocuktan istismar öyküsünün alındığı bu basamak, çocuğun cinsel istismarın belirtileri açısından değerlendirildiği ve müdahale basamağına geçiş öncesi kritik bir aşamadır. Çünkü bu aşama yapılacak doğru değerlendirmeler ve çocuktan alınacak tutarlı hikayeler, sunulacak olan sağaltım sürecinin planlanması üzerinde doğrudan etkili olacaktır. Bundan dolayı, bu aşamada istismar mağduru çocukla ilk görüşmeyi yapacak kişinin, çocuğun duygusal, düşünsel ve davranışsal tüm dinamiklerini birlikte değerlendirerek, ilk görüşme planını dikkatli şekilde hazırlaması ve olayın öyküsünü görüşme sonunda en ince ayrıntısına kadar raporlandırması gerekmektedir.

\section{Üçüncü Düzey Müdahale (Olay Sonrası)}

Bu basamak cinsel istismar mağduru çocukta meydana gelmiş uzun soluklu olumsuz etkilerin tedavisinin düzenlendiği aşamadır. Bu aşama ilk görüşme sırasında kullanılan teknik ve yöntemlerin yanında;

- Bilişsel Davranışçı Terapi (BDT) temelli dinamik oyun terapisi

- Klasik BDT

- Göz hareketlerini duyarsızlaştırma terapisi (EMDR)

- Oyun Terapisi

- İstismar Odaklı BDT

- Travma Sonrası Stres Bozukluğuna dayalı BDT

- Terapötik çocuk gelişim yaklaşımı

-Travma odaklı bütünleşik terapi

- Travma odaklı oyun terapisi

- Grupla psikolojik danışma yaklaşımı teknikleri de kullanılmaktadır.

Bu basamakta hangi teknik kullanılırsa kullanılsın aşağıda ifade edilen temel basamakları içermek zorundadir. Bunlar;

- Emniyet

- Güven ve bağlanma

- İş birliği

- Destek kaynaklarının oluşumu 
- Toplumsal ve sosyal yeni ilişkilerin tanımlanması

- Akran desteğinin kullanımı

-Duygusal, düşünsel ve davranışsal yapilandırma (Müdahale Aşaması)

-Tekrarlamayı önleme, güçlendirme, takip gibi basamaklar yer almalıdır.

Yukarıda sıralanan oyun terapisi ve tekniklerine ikinci düzey müdahale basamağında yer verildiğinden bu aşamada sadece cinsel istismar mağduru çocuklardaki tedavi gücü deneysel olarak sınanmış olan travma odaklı bilişsel davranışçı terapi açıklanacaktır. Çünkü alan yazında, travma odaklı bilişsel davranışçı terapinin, cinsel istismar mağduru çocukların sağaltımı üzerindeki etkisini rapor eden çalışmalar sınırlı olmakla birlikte diğer tedavi yaklaşımlarından daha fazla yer almaktadır.

\section{Cinsel İstismara Uğraşmı̧ Çocukların Tedavisinde Travma Odaklı Bilişsel Davranışçı Terapi}

\section{Yaklaşımı}

\section{Gerekçe ve İşleyiş}

Cinsel istismara uğrayan çocukların çoğuna (\%85'e yakını) psikiyatrik bir tanı konulduğu saptanmıstır (Aktepe, Hesapcioğlu ve Kandil, 2010; Vural ve ark., 2013). Alan yazında cinsel istismara mağduru çocukların en çok yaşadığı sıkıntı ve belirtiler travma sonrası stres tepkilerinden olan kaygı, korku ve depresyondur (Dönmez ve ark., 2014; Şimşek ve ark., 2011). Bilişsel davranışçı terapi ise cinsel istismar dışında ortaya çıan travma sonrası stres belirtileri etkili bir şekilde işleyebilmektedir (Cohen ve Mannario, 1996). Diğer açıdan travma odaklı bilişsel davranışçı terapi çocuk ve ergenlerle yapılan çalışmalarda olumlu sonuçlar vermiştir (Lipsey ve Wilson, 1993; Weisz ve ark., 1995). Bilişsel davranışçı terapideki bu başarllı sonuçlar bu terapi yönteminin cinsel istismar mağduru çocukların tedavisinde de kullanılması fikrini geliştirmiştir (Cohen ve Mannario, 1993).

Bilişsel davranışçı terapi yaklaşımı çocuk ve ergenlerin tedavisinde sık olarak kullanılmaya başlanmıştır (Karakaya ve Öztop, 2013; Özcan ve Gül Çelik, 2017). Bilişsel davranış̧̧ terapi çocuklarda da yetişkinlere benzer tedavi protokollerine sahip olmasına karşın çeşitli farklılıklar barındırmaktadır. İlk farklılık bilişsel davranışçı terapinin çocuğa aktarılması sürecidir (Süler, 2018). Çünkü çocukların bilişsel gelişim düzeyleri yetişkinlerden ve birbirlerinden farklı olduğu için otomatik düşünce, ara inanç, temel inanç ve bilişsel çarpıtma kavramlarının çocuğun anlayabileceği bir seviyeden anlatılması gerekir. Bu süreçte benzetmelerden, hikâyelerden faydalanarak soyut olan bu kavramların somutlaştırılması gerekmektedir (Young ve Brown, 1996). İkinci farklılık ise bilişsel davranış̧̧ terapi zaman ve teknik açısından çok fazla yapılandırılmış olmasından dolayı çocuğun dikkat süresi ile sıkılma durumunun oluşabilmesidir. Bu nedenle çocukla sürdürülen bilişsel davranışçı terapinin süresi ve mola zamanları ayarlanarak, çocuğun sıkılmasının önüne geçilmelidir. Üçüncü farklılık da ev ödevlerinin yapılmasıdır. Bu süreçte çocuk aşırı yapılandırılmış bir tedavi sürecinden geçtiği için evde de aynı etkinlikleri ve ödevleri yapma konusunda sıkılması muhtemeldir. Bu nedenle çocukla sürdürülen bilişsel davranışçı terapide kademeli olarak ödevler verilmeli ve aile de çocuğun ödevini tamamlaması için destek sağlamalıdır.

Çocuklarla yapılan bilişsel davranışçı tedavi yaklaşımlarında aşağıdaki yöntem ve tekniklerden faydalanılmaktadır:

1. Psiko Ë̆itim: Bu tekniğin amacı çocuğu stres kaynaklarına karşı güçlendirmek ve olası stres kaynaklarına karşı çocuğa mücadele edebilme becerisi kazandırmaktır. 
2. Duygularm Fark Etme ve Tamma: Bu aşamada terapist çocuğun duygularına odaklanmasını sağlayarak bu duyguya sebep olan faktörleri değerlendirmesine katkı sağlar. Burada çocuğa duyguların tanıtılması için yüz ifadesi kartlarından ve başka görsellerden faydalanarak duyguların somutlaştırılması sağlanır.

3. Bilişsel Yeniden Yapılandırma: Çocuk danışanlar yetişkinler gibi bilişsel süreçlerinin farkında olamamakta ve günlük hayatta kendisini etkileyen otomatik düşüncelerinin farkında olamayabilirler. Bu aşamada bilişsel davranışçı terapinin düşünsel eğitim protokolleri çocuğun anlayabileceği bir şekilde gerçekleştirilir. Ancak bu süreçte bilişsel davranışçı terapinin kavramları (otomatik düşünce, ara inanç, bilişsel çarpıtma vb.) çocuğun anlaması için yaşantısıyla bağlantı kurularak veya benzetmelerden faydalanılarak anlatilmalıdır.

4. Gevseme Eğitimi: Çalışma sırasında travmatik olayın bilince yeniden çıkarılması ve işlenmesi aşamasında çocukta meydana gelecek bedensel yakınmalar, semptomlar için ve sakin kalabilmesi için çocuğa kas ve nefes egzersizleri öğretilmelidir.

5. Maruz Bırakma: Genellikle kayg1 ve korku tedavisinde kullanılan maruz bırakma için çocuğun düşünsel ve duygusal olarak hazır olup olmadığ1 kontrol edilmelidir. Bu aşamada en az kaygıyı ve korkuyu oluşturacak durumdan en fazla olana doğru planlama yaparak çalışma sürdürülmelidir.

\section{Çocuk Cinsel Ístismant ve Bilişsel Davranış̧ı Terapinin Sağaltım Gücü}

Bilişsel davranışçı terapinin çocuklarla gerçekleştirilen uygulamalarının değerlendirildiği yüz bir araştırmadaki örneklem grubundaki çocukların yaş seviyesinin on ve altında olduğunu görülmektedir. (Durlak ve vd., 1995). Ayrıca çocuklarda bilişsel davranışçı terapinin idrar ve dişkı kaçırma, okula uyum sorunu, somatiszasyonlar, travma sonrası stres tepkilerinin tedavileri üzerinde etkili olmuşlardır (Ronen, 1993; Ronen ve vd., 1995; King ve vd., 1998; Saunders ve vd.,1994; Cohen ve Mannarino, 1996; Deblinger ve vd., 1990).

Deblinger ve arkadaşları (1990) cinsel istismar mağduru 19 kız çocuğu ile on iki oturumluk travma odaklı bilişsel davranışçı terapi seansları düzenlemişlerdir. Çalışmaya başlamadan önce çocukların travmatik belirtileri taranmış ve çocuklara depresyon ölçeği ve sürekli kaygı envanteri uygulanmıştır. Çalışma sonucunda bu ölçme araçları çocuklara yeniden uygulanmış ve ölçeklerden alınan puanlarda iyileşme olduğu görülmüştür.

Diğer bir çalışmada (Cohen ve Mannarino, 1997) 67 cinsel istismar mağduru okul öncesi çocuk rastgele iki gruba ayrılarak bir gruba travma odaklı bilişsel davranış̧̧ı terapi diğer gruba ise yönlendirici olmayan destekleyici terapi yöntemi uygulanmıştır. Bu sırada ailelere çocuk davranışları takip formu, çocuklar için cinsel davranış takip formu uygulanmıştır. On iki oturum süre sonunda yönlendirici olmayan tedavi grubundaki çocuklarda hiçbir iyileşme meydana gelmediği, ancak travma odaklı bilişsel davranışçı terapi grubunda olan çocuklarda semptomların iyileşme gösterdiği gözlenmiştir.

Berliner ve Saunders (1996) tarafından cinsel istismara uğramış 4-13 yaş arasındaki 80 çocuk için oluşturulmuş olan bilişsel davranışçı terapi temelli bir grup tedavi programının çocukların korku ve kaygıları üzerinde etkisi incelenmiştir. Uygulama sonunda çocuklardaki kaygı ve korku belirtilerinde anlamlı düzeyde azalmalar gözlenmiştir. Yapılan başka bir çalışmada (Cohen ve Mannario, 1998) bilişsel davranışçı terapi ile 
yönlendirici olmayan tedavinin cinsel istismara uğramış 7-14 yaş grubu çocukların travma sonrası belirtileri üzerindeki etkisi incelenmiştir. Çalısmanın sonucunda bilişsel davranışçı terapi grubundaki çocukların olumsuz belirtilerinde iyileşmenin diğer gruptaki çocuklara göre daha fazla olduğu sonucuna ulaşılmıştır.

Deblinger ve arkadaşları (1996) cinsel istismara uğramış çocukların travma sonrası stres, duygusal ve davranışsal zorluklarını tedavi etmek için bilişsel davranışçı terapi yaklaşımını kullanmışlardır. Deneysel modeldeki çalısmanın bulguları, bilişsel davranışçı terapi uygulanan çocukların travma sonrası stres belirtilerinin diğer gruptaki çocuklara göre anlamlı bir şekilde azalma gösterdiğini ortaya koymuştur.

\section{Tartışma}

Cinsel istismara uğramış çocukların, yaşamış oldukları olayın etkilerinden kurtulmaları çok zor olmaktadır. Diğer yandan cinsel istismar mağduru çocukların sağaltım süreçleri çok uzun soluklu olabilmektedir (Teeuw, Derkx, Koster ve van Rijn, 2012). Yaşamış olduğu travmatik durumun etkileri daha ileriki yaşlarda dahi ortaya çıkabilmektedir. Küçük yaşlarda cinsel istismara uğrayan çocukların dil ve iletişim becerilerindeki zayıflıklardan ötürü, istismar durumunun ortaya çıkması zor olabilmektedir (Paine ve Hansen, 2002). Ayrıca çocukların istismar olayını kendilerinin ve ailelerinin başlarına kötü şeyler geleceği korkusundan dolayı gizleme eğilimi gösterdikleri bilinmektedir (De Voe ve Faller, 1999). Yukarıdaki araştırma sonuçları ve kuramsal bilgilerden anlaşılacağı üzere, çocuklarda cinsel istismar olgusu çok fazla yıkıcı etkiye sahip olan, ortaya çıkarılması ve saptanması kolay olmayan yıkıı bir psikolojik süreçtir. Bundan dolayı, çocukların kişisel ve bedensel mahremiyetleri konusunda okul ve aile temelli önleyici çalışmaların olabildiğinde en erken zamanda yapılması bu aşamada atılacak önemli adımlardan biridir.

Birinci basamak müdahale hizmetleri daha okul ortamında çocuklara ve ailelerine yönelik sunulan bilgilendirici ve önleyici hizmetler olarak karşımıza çıkmaktadır. Alan yazındaki çalışmaların sonuçları ile uygulamadaki çalışmalar (önleyici ve koruyucu çalışmalar) incelendiği zaman, okullarda veya başka ortamlarda yapılan önleyici çalışmaların, çocukların cinsel istismar mağduru olma ve ilerleyen zamanlarda istismara maruz kalma oranlarının daha düşük olduğunu bildiren araştırmalar bulunmaktadır (Davis ve Gidyez, 2001; Gibson ve Leitenberg, 2000). Bu sonuçlar alan çalışanlarına ve okul personellerine büyük sorumluluklar yüklemektedir. Bu sorumluluğun nedeni olarak ise; çocuk cinsel istismarı ile mücadeledeki önleyici hizmetlerin kilit noktasının okullar olması söylenebilir. Çocuklar cinsel istismardan korunmaya yönelik bir eğitimle hayatlarında ilk defa okul ortamlarında karşılaştıkları için, bu aşamada sunulacak hizmetin niteliğinin çok iyi olması gerekmektedir. Alan yazında bulunan çeşitli araştırmalarda (Gibson ve Leitenberg, 2000; Koçtürk, 2018; 2019; Lundgren ve Âmin, 2015) okul ortamında verilen koruyucu ve önleyici eğitimlerin önemlerine vurgu yapmaktadır. Bu sonuçlardan hareketle, ilk çocukluk çağında hem ailelere hem de çocuklara yönelik verilecek olan mahremiyet eğitimleri ile, istismardan korunma yolları ve yardım kaynakları konulu eğitimlerin çocukların ihmal ve istismar mağduru olma risk faktörleri üzerinde azaltıcı bir etkiye sahip olduğuna işaret edilmektedir. Bundan dolayı çocuk cinsel istismarı ile mücadeledeki en kritik basamak olan birinci düzey müdahale hizmetlerinin tüm okullarda planlı ve aktif bir şekilde sürdürülmesi, bu konuda önde gelen sorumlulardan olan öğretmen ve okul yönetimlerinin bu çalısmalara aktif bir şekilde katılmalarının, çocukların cinsel istismar mağduru olma sıklıklarında azaltacağı düşünülebilir. 
Çocukluk çağı cinsel istismar olgusunun diğer bir sancilı sürecinin ise olayın ifşası olduğu görülmektedir. Çünkü istismar mağduru çocuğun bu durumu açığa vurması ve anlatması her zaman mümkün olmadığ1 görülmektedir. Diğer açıdan bu aşamada hem olay mağduru çocuk hem de olayı ilk duyan kişiler (aile, arkadaş, öğretmen vb.) cinsel istismar durumunu bildirme konusunda çekinceler yaşadığından, sürecin herkes açısından hassas bir şekilde yürütülmesi ve hiçbir adımın atlanmaması gerekmektedir (Sternberg ve ark., 1996). Alan yazın incelendiği zaman istismar mağduru çocuklardan doğrudan olayı anlatmasını istemek yerine resim çizme, oyun terapisi, kum terapisi, öykü ve kitap okuma gibi tekniklerin kullanılması önerilmektedir. Bu tekniklerin çocukların yaşamış oldukları kaygı ve korku hislerini azaltarak, istismar olayını daha rahat ifade edebildikleri söylenebilir. Alan yazında yapılan çalışmaların sonuçları buna işaret etmektedir (Dedeler, Öztop ve Öztürk, 2016; Herman, 1997; Katz, Barnetz ve Hershkowitz, 2005).

Cinsel istismar olgusunda, kuramsal açıklamalar ve araştırma sonuçlarına göre, travma odaklı bilişsel davranışçı terapinin cinsel istismar mağduru çocukların sağaltımında kullanılan etkili bir tedavi yaklaşımı olduğu ifade edilmektedir. İstismar mağduru çocukların, olay sonrası kendilerine, aile bireylerine ve çevresine karşı çarpıtılmış düşünceler geliştirebildikleri görülmüştür (Cohen ve Mannario, 1996). Travma odaklı bilişsel davranışçı yöntem yardımı ile, istismar mağduru çocuğun düşünsel yapısı yeniden onarılarak, travmatik durumun çocuğa verdiği duygusal zararın en aza indirilmesi amaçlanmaktadır (Berliner ve Saunders, 1996; Cohen ve Mannario, 1998). Bu nedenle deneysel olarak sınanmış olan travma odaklı bilişsel davranışçı terapinin, cinsel istismar mağduru çocukların sağaltım sürecinde en etkili yöntem olduğu söylenebilir.

Sonuç olarak; çocuk cinsel istismarının çocuklar için ağır travmatik sonuçlanı bulunduğundan dolayı, her aşamasında zorlu süreçlerin bulunduğu bir olgudur. Çocuk cinsel istismarı hem mağdur çocukta hem de toplum içerisinde derin yaralar açtığ için bu konuda okul, aile ve sosyal paydaşların her türlü hassasiyeti göstermesi gerekmektedir. Alan yazının işaret ettiği gibi aile ve çocuklar için düzenlenen okul tabanlı cinsel istismardan korunmaya yönelik önleyici çalışmaların çocukların istismar mağduru olmamalarında kritik bir yol üstlendiğinden dolayı bu çalışmalar en üst düzeyde hassasiyetle sürdürülmesinin gerekliliği sonucu ortaya çıkmaktadır.

\section{Öneriler}

\section{Araştırmacılara Öneriler}

Alan yazında daha çok cinsel istismar ve ihmalin tanı kriterleri ve belirtileri üzerine çalışmalar bulunmaktadır. Ancak sağaltım süreçleri ve önleyici çalışmaların etkililiğinin incelendiği deneysel çalısmalara daha az rastlanmaktadır. Bu nedenle çocuk cinsel istismarındaki önleyici programların değerlendirildiği çalışmalar yapılabilir. Diğer açıdan önleyici çalışmalar ile olayın ortaya çıkarılması konusunda kilit rol oynayan okul psikolojik danışmalarının bu konudaki bilgi ve müdahale becerilerinin değerlendirildiği nitel bir araştırma yapılabilir. Yine başka bir çalışmada çocuk cinsel istismarına yönelik yurt dışında uygulanan birinci düzey, ikinci düzey ve üçüncü düzey müdahale basamakları ve ilgili çalışmalar incelenerek, Türk kültürüne uyarlama ve etkililiğinin değerlendirildiği çalışmalar düzenlenebilir. 


\section{Alana Yönelik Politika Üreticilere Öneriler}

Çocuk cinsel istismarı toplumsal açıdan çok ağır sonuçları olan vakalar olduğundan dolayı ilgili kurumlar sosyal hayatta, okulda ve ailede meydana gelebilecek istismar olaylarına yönelik önleyici çalışmaları arttırarak sürdürmelidir. Diğer açıdan Millî Eğitim Bakanllğı bünyesinde bulunan tüm öğretmenler ve diğer paydaşlara yönelik çocuk cinsel istismarının belirti ve bulguları konusunda eğitimler verilerek bu konudaki farkındalık düzeyleri arttırılabilir. Bu sayede çocukların tekrarlayan istismara maruz kalmalarının önüne geçilmesi konusunda önleyici bir hizmet sunulmasına katkı sağlanabilir. Ayrıca reklamlar, diziler ve diğer medya araçları sürekli kontrol edilerek, çocuklar üzerinden cinsel kazamın elde etmeye çalşan veya çocukları yaşına uygun olmayan ortamlarda sunan kuruluşlara müdahale edilerek bu konuda çeşitli yaptırımlar uygulanmalıdır. Son olarak toplumu çocuk cinsel istismarına yönelik bilinçlendirmek ve bireylerin bu konudaki yasal sorumlulukları konusunda farkındalık düzeylerini arttırmak için kamu spotları oluşturulabilir.

\section{Atıf için (How to cite)}

Yam, F.C. (2020). Çocuk Cinsel İstismarına Yönelik Müdahale Basamakları ve İşlevlerinin Kuramsal Olarak İncelenmesi. Çocuk ve Gelişim Dergisi, 3(5), 61-78. 


\section{Kaynakça}

Akduman G, Ruban C, Akduman B, Korkusuz İ. (2005). Çocuk istismarı ve ihmali: psikiyatrik yönleri. Adli Psikiyatri Dergisi, 3, 9-14.

Acehan, S., Bilen, A., Ay, M. O., Gülen, M., Avci, A. ve İçme, F. (2013). Çocuk istismarı ve ihmalinin değerlendirilmesi. Arşiv Kaynak Tarama Dergisi, 22(4), 591-614.

Avellar SA. ve Supplee LH. (2013). Effectiveness of home visiting in improving child health and reducing child maltreatment. Pediatrics, 132 (2), 90-99.

Aktepe, E., Işsk, A., Kocaman, O. ve Eroğlu, F.Ö. (2013). Bir üniversite hastanesinde değerlendirilen cinsel istismar mağduru çocuk ve ergenlerin demografik ve klinik özellikleri. New Symposium Journal, 51 (2), 115-120.

Alaggia, R. (2005). Disclosing the trauma of child sexual abuse: A gender analysis. Journal of loss and Trauma, 10(5), 453-470.

Ayan, S. ve Gökkaya, V. B. (2018). Child sexual abuse: The relationship between the type of abuse and the risk factors. Journal of Human Sciences, 15(2), 816-822.

Berliner, L. ve Saunders, B.E. (1996). Treating fear and anxiety in sexually abused children: Results of a controlled 2-year follow-up study. Child Maltreatment, 1(4), 294-309.

Bulut, S. (2016). Erken çocukluk dönemi cinsel istismarının psikodinamik oyun terapisiyle teşhisi ve tedavisi. Türk Psikolojik Damssma ve Rebberlike Dergisi, 3(29), 131-144.

Bozkurt, G., Yorulmaz, C. ve Düzkaya, D. S. Çocuklarda cinsel istismara bağlı travma sonrası stres bozukluğu: Olgu analizi. Sağhk Bilimleri ve Meslekleri Dergisi, 1(2), 68-74.

Cohen, J.A. ve Mannarino, A.P. (1993). A treatment model for sexually abused preschoolers. Journal of Interpersonal Violence, 8, 115-131

Cohen, J. A. ve Mannarino, A. P. (1996). A treatment outcome study for sexually abused preschool children: Initial findings. Journal of the American Academy of Child \& Adolescent Psycbiatry, 35(1), 42-50

Cohen, J.A. ve Mannarino, A.P. (1998). Interventions for sexually abused children: Initial treatment findings. Child Maltreatment, 3, 17-26.

Çeçen, A. R. (2007). Çocuk cinsel istismarı: Sıklığ1, etkileri ve okul temelli önleme yolları. Uluslararası İnsan Bilimleri Dergisi, 4(1).

Dube, R. ve Herbert,M. (1988). Sexual abuse of children under 12 years of age: A review of cases. Child Abuse and Neglect, 12,321-330.

Davis, K.M. Gidyez,C.A.(2001). Review: School based child sexual abuse prevention programs are effective for improving prevention skills and knowledge. Evidence Based Mental Health, 2,12-14.

Deblinger, E., Lippmann, J. ve Steer, R. (1996) Sexually abused children suffering posttraumatic stress symptoms: Initial treatment outcome findings. Child Maltreatment, 1, 310-32.

Deblinger, E., McLeer, S.V. ve Henry, D. (1990) Cognitive behavioural treatment for sexually abused children suffering post-traumatic stress disorder: preliminary findings. Journal of the American Academy of Child and Adolescent Psychiatry 29, 747-52.

Durlak, J. A., Furnham, T. ve Lampman, C. (1991). Effectiveness of cognitive-behaviour therapy for maladapting children: A meta-analysis. Psychological Bulletin 110, 204-214.

Dönmez, Y. E., Soylu, N., Özcan, Ö. Ö., Yüksel, T., Demir, A. C.., Bayhan, P. Ç. ve Miniksar, D. Y. (2014). Cinsel istismar mağduru çocuk ve ergen olgularımızın sosyodemografik ve klinik özellikleri. Turgut Özal Tip Merkezi Dergisi, 21(1), 44-48.

DeVoe, E. R. ve Faller, K. C. (1999). The characteristics of disclosure among children who may have been sexually abused. Child Maltreatment, 4(3), 217-227.

Dedeler, M., Öpöz, T. ve Öztürk, C. (2016). Çocukluk Çağ1 Cinsel İstismarına Yönelik Tedavi ve Önleme Yaklaşımları: Bir Gözden Geçirme. AYNA Klinik Psikoloji Dergisi, 3(1), 1-16.

Eslek, D. (2018). Erken ergenlik döneminde çocuk cinsel istismarm önleme programınin etkililigünin incelenmesi. Yüksek lisans tezi, Ege Üniversitesi, Sosyal Bilimler Enstitüsü, İzmir. 
Fang X, Fry DA, Brown DS, Mercy JA, Dunne MP, Butchart AR, Corso PS, Maynzyuk K, Dzhygyr Y, Chen Y, McCoy A. ve Swales DM. (2015). The burden of child maltreatment in the East Asia and Pacific region. Cbild Abuse ve Neglect, 42, 146-162.

Fergusson, D. M., Horwood, L. J. ve Lynskey, M. T. (1996). Childhood sexual abuse and psychiatric disorder in young adulthood: II. Psychiatric outcomes of childhood sexual abuse. Journal of the American Academy of Child ve Adolescent Psychiatry, 35(10), 1365-1374.

Finkelhor, D. (1990). Sexual abuse in a national survey of adult men and women: prevalence, characteristics and risk factors. Child Abuse and Neglect, 14, 19-28.

Feiring, C., Taska, L. ve Lewis, M. (1999). Age and gender differences in children's and adolescents' adaptation to sexual abuse. Child Abuse \& Neglect, 23(2), 115-128.

Fergusson, D. M., Horwood, L. J. ve Lynskey, M. T. (1997). Childhood sexual abuse, adolescent sexual behaviors and sexual revictimization. Child Abuse \& Neglect, 21(8), 789-803.

Gilbert, R., Widom, C. S., Browne, K., Fergusson, D., Webb, E. ve Janson, S. (2009). Burden and consequences of child maltreatment in high-income countries. The lancet, $373(9657)$, 68-81. Gümüş, A. E. (2017). Çocuk cinsel istismarı şüphesinin bildirimi öncesinde çocukla yapılacak ilk görüşme. Klinik Psikiyatri Dergisi, 20(1), 45-58.

Geldard, K. ve Geldard, D. (2013). Ergenler ve gençlerle psikolojik danışma. (Çev. Ed. M. Pişkin). Nobel Akademik. Yaymollk, İstanbul.

Grubbs, G. A. (1995). A comparative analysis of the sandplay process of sexually abused and nonclinical children. The Arts in Psychotherapy.

Gibson, L. E. ve Leitenberg, H. (2000). Child sexual abuse prevention programs: Do they decrease the occurrence of child sexual abuse?. Child Abuse \& Neglect, 24(9), 1115-1125. Goodman-Brown TB, Edelstein RS, Goddman GS, Jones DP, Gordon DS. Why children tell: A model of children's disclosureof sexual abuse. Child Abuse Negl 2003; 27: 525-540.

Aktepe, E., Hesapcıoğlu, S. T. ve Kandil, S. (2010). Cinsel istismar mağduru olan çocukların başvuru şekilleri, klinik ve sosyodemografik özellikleri.. SDÜ Tip Fakültesi Dergisi, 17(4), 15-21. Herman, L. (1997). Goodenough fairy tales for resolving sexual abuse trauma. The Arts in Psychotherapy, 24(5), 439-445.

Homeyer, L.E. ve Landreth, G.L. (1998). Play therapy behaviors of sexually abused children. International Journal of Play Therapy, 7(1), 49-71.

Hershkowitz, I., Lanes, O. ve Lamb, M. E. (2007). Exploring the disclosure of child sexual abuse with alleged victims and their parents. Child Abuse \& Neglect, 31(2), 111-123. Hershkowitz, I. (2002). The role of facilitative prompts in interviews of alleged sex abuse victims. Legal and Criminological Psychology, 7(1), 6371.

Irmak, T. Y., Kızıltepe, R., Aksel, Ş., Güngör, D. ve Eslek, D. (2018). Mika ile kendimi korumayı öğreniyorum: cinsel istismarı önleme programının etkililiği. Türk Psikoloji Dergisi, 33(81), 41-61.

Jenny, C., Roesler, T. A. ve Poyer, K. L. (1994). Are children at risk for sexual abuse by homosexuals? Pediatrics, 94, 41-44.

Karakaya, E. ve Öztop, D. B. (2013). Cognitive behavioral therapy in children and adolescents with anxiety disorder. Journal of Cognitive-Behavioral Psychotherapy and Research, 2(1), 10-24.

Katz, C., Barnetz, Z. ve Hershkowitz, I. (2014). The effect of drawing on children's experiences of investigations following alleged child abuse. Child Abuse \& Neglect, 38, 858-867.

Kaytez, N., Yücelyiğit, S. ve Kadan, G. (2018). Child abuse and solution proposals. Avrasya Sağhlk Bilimleri Dergisi, 1(1), 18-24.

Kır, E. (2013). Çocuklara yönelik cinsel taciz ve istismara karşı önleyici eğitim çalışmaları. İstanbul Üniversitesi Hukuk Fakültesi Mecmuasi, 71(1), 785-800.

King, N. J., Tonge, B. J., Heyne, D., Pritchard, M., Rollings, S., Young, D., Myerson, N. ve Ollendick, T. H. (1998). Cognitive behavioural treatment of school-refusing children: a controlled evaluation.Journal of the American Academy of Child and Adolescent Psychiatry 37, 395-403. 
Koçtürk, N. (2019). Tekrarlanan cinsel istismar mağduriyeti ve okul ortamında yapılması gerekenler. İnsan ve Toplum Bilimleri Arasstrmalar Dergisi, 8(2), 965-990.

Koçtürk, N. (2018). Çocuk ihmalini ve istismarını önlemede okul çalışanlarının sorumlulukları.

Muğla Sıtkı Koçman Üniversitesi Eğitim Fakïltesi Dergisi, 5(1), 38-47.

Lereya ST., Samara M. ve Wolke D. (2013). Parenting behavior and the risk of becoming a victim and a bully/victim: A meta-analysis study. Child Abuse \& Neglect, 37; 1091-1108.

Lipsey, M. W. ve Wilson, D. B. (1993). The efficacy of psychological, educational, and behavioral treatment: Confirmation from meta-analysis. American Psychologist, 48(12), 1181-1209.

Lundgren, R. ve Amin A. (2015). Addressing intimate partner violence and sexual violence among adolescents: Emerging evidence of effectiveness. Journal of Adolescent Health,56, 542-550. Mannarino, A. P, Cohen, J. A. (1986). A clinical-demographic study of sexually abused children. Child Abuse and Neglect, 10, 17-23.

Paine, M. L. ve Hansen, D. J. (2002). Factors influencing children to self-disclose sexual abuse. Clinical Psychology Review, 22(2), 271-295.

Pelcovitz, D., Kaplan, S., Goldenberg, B., Mandel, F., Lehane, J. ve Guarrera, J. (1994). Post-traumatic stress disorder in physically abused adolescents. Journal of the American Academy of Child \& Adolescent Psychiatry, 33(3), 305-312.

Renvoize, J., (1993). Innocence Destroyed: A Study of Sexual Abuse. London: Routledge.

Ronen, T. (1993). Intervention package for treating encopresis in a 6-year-old boy: a case study. Behavioural Psychotherapy 21, 127-35.

Ronen, T., Rahav, G. ve Wozner, Y. (1995). Self-control and enuresis. Journal of Cognitive Psychotherapy: an International Quarterly, 9, 249-58.

Süler, M. (2018). Çocuk ve ergenlerde bilişsel davranişçi terapi uygulamalari: Bir gözden geçirme. Çocuk ve Medeniyet Dergisi, 2(3), 20-42.

Sternberg KJ, Lamb ME, Hershkowitz I, Esplin PW, Redlich A. ve Sunshine N. (1999). The relation between investigative utterance types and the informativeness of child witnesses. Journal of Applied Developmental Psychology, 17(3), 439-451.

Shapiro DL. ve Levendosky AA. (1999). Adolescent survivors of childhood sexual abuse: the mediating role of attachment style and coping in psychological and interpersonal functioning. Child Abuse and Neglect, 23, $1175-1191$. 